๑ Entomologica Fennica. 19 April 2002

\title{
Ecology and conservation status of Acanthocinus griseus (Fabricius, 1792) (Coleoptera: Cerambycidae) in Finland
}

\author{
Petri Martikainen
}

\begin{abstract}
Martikainen, P. 2002: Ecology and conservation status of Acanthocinus griseus (Fabricius, 1792) (Coleoptera: Cerambycidae) in Finland. — Entomol. Fennica 13: 41-50.
\end{abstract}

The ecology and occurrence of Acanthocinus griseus in Finland is described to explain why this rarity was excluded from the latest national Red List. Careful examination of several trees inhabited by the species showed that the habitat requirements of $A$. griseus are in fact rather broad, contrary to previous assumptions. Acanthocinus griseus can breed in almost any part of the trunk of freshly dead, standing spruce and pine trees. All finds were made in normal managed forests or in burned areas. High mortality was observed during the larval stage due to parasitoids and predators. Adults of A. griseus live a cryptic life and larvae are difficult to find without experience, which may explain the low number of observations in Finland. Acanthocinus griseus is clearly an overlooked species and detailed examination of suitable trees would without doubt reveal many new occurrences in this country.

Petri Martikainen, Faculty of Forest Sciences, University of Joensuu, P.O. Box 111, FIN-80101 Joensuu, Finland; E-mail: petri.martikainen@joensuu.fi

Received 28 May 2001, accepted 21 January 2002

\section{Introduction}

The longhorn beetle Acanthocinus griseus (Fabricius, 1792) (Fig. 1) has a wide distribution in the Palaearctic region, ranging from Europe to Japan (Bílý \& Mehl 1989, Bense 1995). In Europe, A. griseus ranges from Spain, Italy and Greece in the south to Norway, Sweden and Finland in the north (Silfverberg 1992, Bense 1995). In Central Europe it is mainly restricted to mountainous areas (Horion 1974, Klausnitzer \& Sander 1978). Acanthocinus griseus is a relatively rare species in most of its European range and it has been included in the list of endangered species in Germany, Sweden, Norway and Finland (Rassi et al. 1992, Ehnström et al. 1993, Geiser 1998, Anon. 1999). However, it was excluded from the
Finnish Red List in the latest update (Rassi et al. 2001). In this article I describe the ecology and occurrence of $A$. griseus in Finland to explain why this assumed "old-growth relict" (Rassi et al. 1985, Ehnström \&Waldén 1986) is no longer regarded as a threatened species in this country.

Despite its wide distribution, information on the biology of this species in Fennoscandia has been scarce and even confusing to some extent. In Gotska Sandön, which is the only locality in Sweden where the species is still fairly common (Ehnström \&Waldén 1986), it has been found breeding in the apical ends of fallen pine trunks and also in fallen branches of pine in shady localities, and adults have been found sitting on timber piles (Lundberg 1964). On the other hand, recent finds in the Dalälven region in Sweden are 


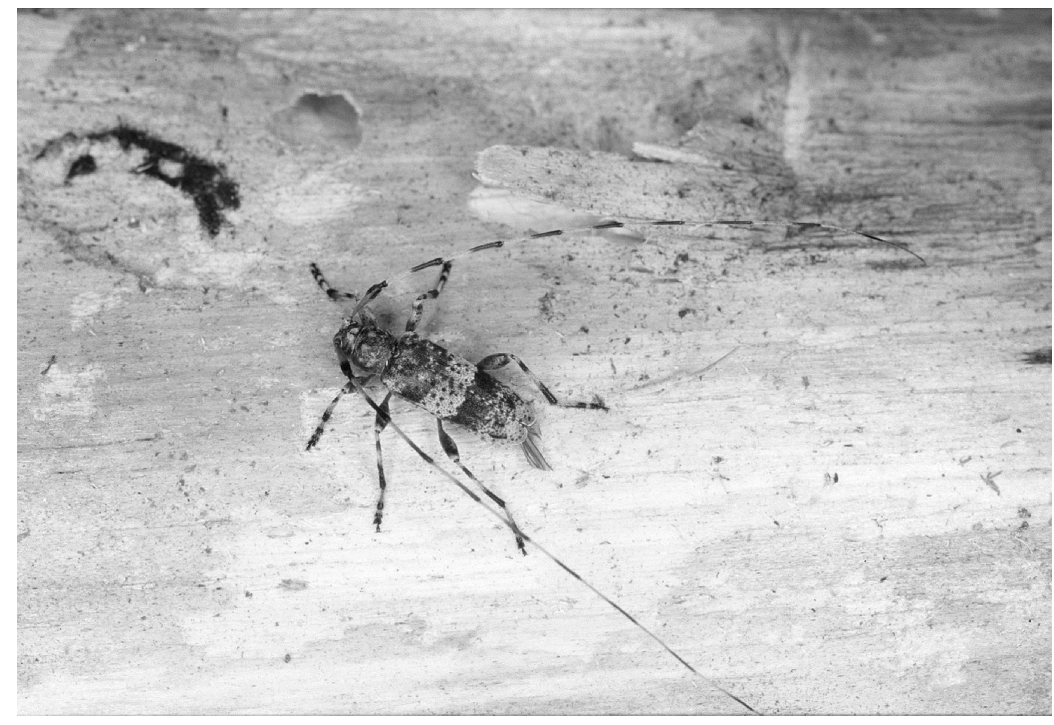

Fig. 1. Adult Acanthocinus griseus. Note the hole leading to pupal chamber $1 \mathrm{~cm}$ above the head of the beetle. from burned pine and spruce trees (Baranowski 1980, Palm 1984). In 1994, R. Pettersson found one pupa under the bark of an Abies sibirica bolt imported from Russia (Lundberg \& Pettersson 1997).

It is rather surprising that there are virtually no published observations on the biology of this species in Finland. Almost all the Finnish records are based on adult beetles that have been found more or less by accident, away from the actual locality of breeding. As far as I know, A. griseus has been reared only five times in Finland prior to this study (S. Lundberg, I. Mannerkoski, J. Muona and J. Perkiömäki, pers. comm.). The first Finnish Red Data Book (Rassi et al. 1985) classified A. griseus as vulnerable and suggested starting its conservation with a detailed study on the ecology and present status in Finland. This paper hopefully provides the information that was requested and, perhaps more importantly, shows that further conservation measures are not needed at the moment.

\section{Material and methods}

I studied the ecology of A. griseus in Sa: Juva, south-eastern Finland during the years 1996-2001. I made the first observation of this species purely by accident when I was studying the occurrence of Trypodendron species in a recently dead spruce (see Martikainen 2000). To obtain more individuals and to get a better idea on the natural history of A. griseus, I first exam- ined thoroughly three recently dead spruce trees with ongoing attacks of this longhorn beetle in the same place (spruce trees 1-3, Fig. 2), on the eastern edge of a recent clearcut. The roots of the spruce trees had been damaged by logging machines, which had obviously contributed to the death of the trees. Trees were felled about one year after their death and cut into $0.5-\mathrm{m}$ bolts, which were then peeled and examined. Signs of scolytids and cerambycids were recorded from each bolt, paying special attention to A. griseus. The diameter of each bolt was measured and the time when each part of the tree had died was deduced by the presence of bark beetles and associated species and by the looseness of bark. Several larvae of A. griseus were reared to adults by placing them back into unpeeled sections of the original bolts. Presence of parasitoids was also noted and some specimens were reared to adults.

After I had learned how to find the species, I checked whether it was occurring in the same region also on pine, as indicated in the literature. For this purpose, I haphazardly selected three standing pines (pine trees 1-3, Fig. 2) which had died in the previous year, $80-400 \mathrm{~m}$ from the original locality. These trees were felled in August 1997 and studied as described above. I also tried to find the species from windthrown spruce and pine trees in the same area, but suitable trees were scarce and the few I examined were possibly too small for the species. As such, the absence of $A$. griseus in these fallen trees does not necessarily indicate that it would not breed in such trees.

Since the above study, I have carefully examined several trees, mostly pines, $1-10 \mathrm{~km}$ from the original locality in Juva and looked for A. griseus less intensively in other places in Finland and Russian Karelia. These observations are described briefly.

I have also gathered records of A. griseus in Finland by searching the literature, by examining the collections of the Zoological Museum in Helsinki, and by directly contacting curators of several museums in Finland and entomologists in Finland and Sweden. 
Fig. 2. Analyses of the trees studied showing signs of $A$. griseus. Only the height where each species occurred was recorded. Thus, the symbols on the graphs indicate the actual height, but not the exact location of galleries around the trunk. In reality, the galleries were often concentrated in rather narrow sectors of the trunk.

\section{Results}

\subsection{Study trees}

The pattern of occurrence of $A$. griseus varied considerably among the intensively studied trees in Sa: Juva, Otamo (Fig. 2).

Spruce 1. The top of the tree had been killed by Pityogenes chalcographus (Linnaeus) one year before the basal part of the tree was attacked by bark beetles. More than 150 empty pupal chambers of $A$. griseus were found in the top of the tree, where the remaining bark was already loose. A high proportion of the pupal chambers had been opened by wood-

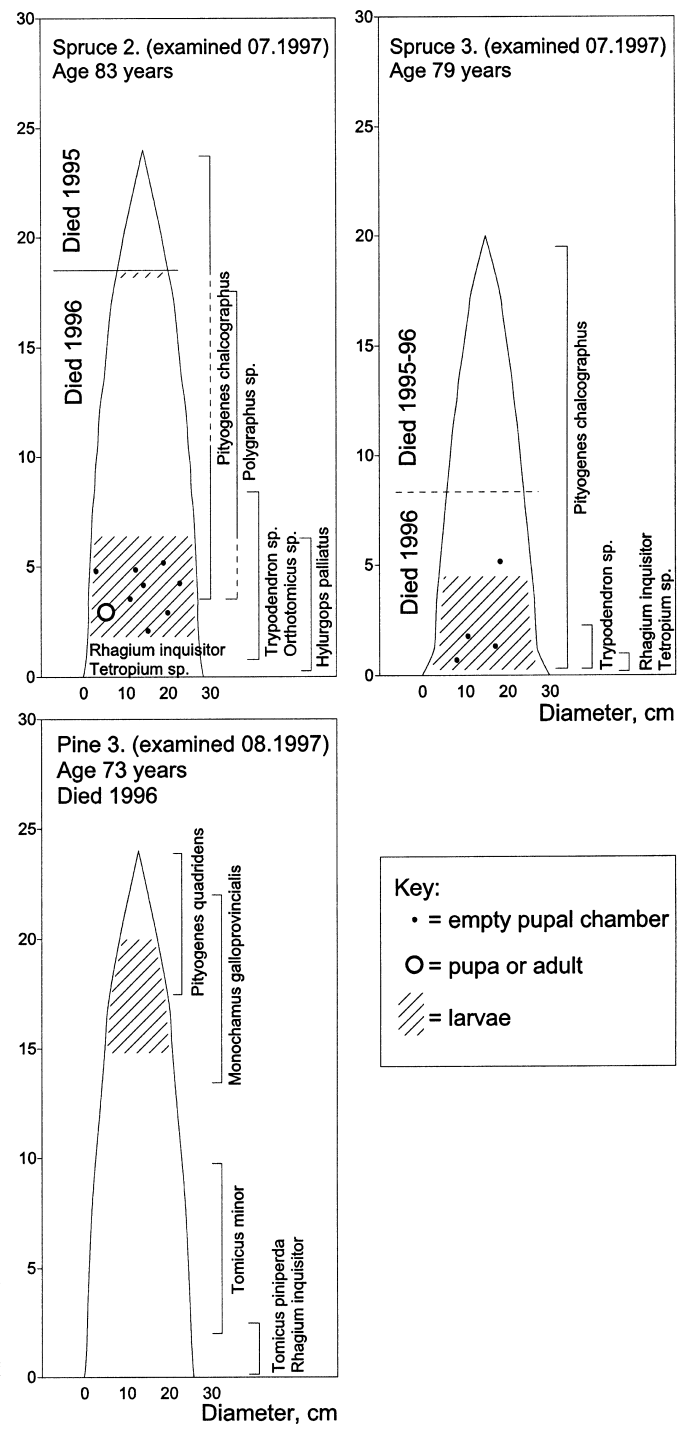

peckers. In the basal part of the tree, there were still bark beetles present. Larvae of $A$. griseus were found from a height of $3.5 \mathrm{~m}$ upwards. Three pupae were also found in this area. In this part of the trunk, 80$90 \%$ of the larvae were parasitised. One specimen of the vulnerable Corticeus longulus (Gyllenhal) was also found in a Trypodendron-hole at a height of $4 \mathrm{~m}$.

Spruce 2. The few larval galleries of A. griseus in the top part of the tree were situated just above the zone of dense attack of Polygraphus spp. Under the zone occupied by Polygraphus spp, larvae and empty pupal chambers of $A$. griseus were found down to a height of $2 \mathrm{~m}$. Over $50 \%$ of the larvae were parasitised. 


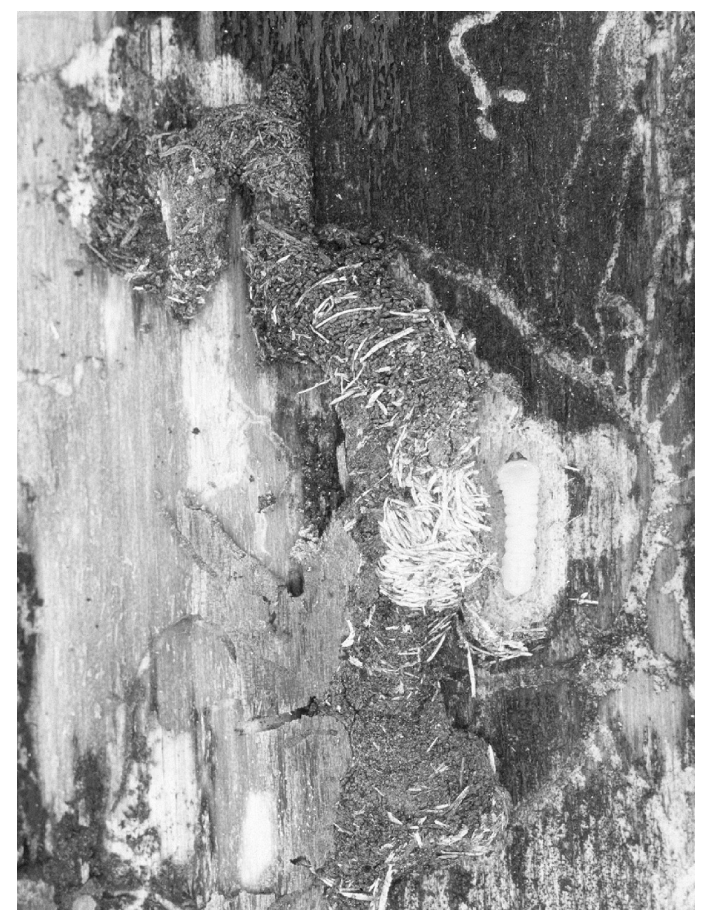

Fig. 3. Larva in a shallow pupal chamber located between wood and bark. Note the whitish wood fibres near the chamber in otherwise brownish frass.

Spruce 3. Bark very dry in most of the trunk. Larvae and a few pupal chambers of A. griseus were found between 0.3 and $5 \mathrm{~m}$. Many of the larvae were in poor condition because of the dryness of the bark.

Pine 1 . This tree, as well as pine 3 , had obviously been killed by an infection of the root rot fungus Heterobasidion sp. Attacks of A. griseus were concentrated in two areas: in the transition zone between Tomicus piniperda (Linnaeus) and T. minor (Hartig), and just above the zone occupied by $T$. minor. Most of the galleries in the top of the tree had failed because of dryness and parasitoids. Few other beetle species were present in the trunk.

Pine 2. No signs of A. griseus were found in this $25-\mathrm{cm}$ thick tree. The tree had been killed by resin-top disease (Endocronartium pini). Most of the trunk was without any signs of beetle attack; the most frequent species were Monochamus galloprovincialis (Olivier), T. piniperda and Pityogenes quadridens (Hartig).

Pine 3. Several larvae of A. griseus were found between 15 and $20 \mathrm{~m}$. M. galloprovincialis was also present in that part of the trunk. Some of the galleries of $P$. quadridens in the top of the tree were fresh. Tomicus piniperda and T. minor had already abandoned the basal part of the trunk.

In addition to the above, I have made the following observations of the species:

- Russian Karelia, near Sortavala 4.V.1998. Dead standing spruces killed by Ips spp. next to a burned clearcut (Martikainen \& Niemelä 2000). Five larvae in their pupal chambers were removed from the basal part of two spruce trees for rearing. Adults emerged after ca. two weeks.

— Kb: Lieksa, Ukonsärkkä 13.V.1998. Burned clearcut with plenty of retained pines. Two parasitised larvae were caught by sieving fallen pieces of bark of a recently dead, largediameter pine.

- Sa: Puumala, Linnomäki 4.IV.1999. Burned ca. 25 year-old pine stand. Five larvae in their pupal chambers were taken from two 8-12 cm diameter dead pines at a height of $0.5-1.0 \mathrm{~m}$. Empty pupal chambers were also observed in other similar trees.

- Sa: Juva, Otamo 9.IV.2000. Dead 20-cm diameter pine near a lakeshore. This tree was felled and examined in detail. The tree had been killed by resin-top disease (E. pini) that occurred at a height of $6 \mathrm{~m}$. Below that, there were $c a .75$ empty and 9 full pupal chambers of $A$. griseus. Most of the empty chambers had been opened by woodpeckers.

— Sa: Juva, Koikkala 13.III.2001. Two recently dead pines were felled and examined throughout. One was very similar to pine 1 (see above) and contained six larvae and a few exit holes at heights of 2, 3, 15 and $17 \mathrm{~m}$.

It seems that $A$. griseus can occur in almost any part of the trunk. Quite often the galleries are concentrated in areas where the dominant bark beetle species is changing and the total density of bark beetle galleries is lower than average. The very basal part of the trunk $(0-1.5 \mathrm{~m})$ is usually heavily attacked by large cerambycids such as Rhagium inquisitor (Linnaeus), Tetropium spp. and Acanthocinus aedilis (Linnaeus), which makes it difficult to find galleries of A. griseus even if they were present. I also studied several branches from each tree, but did not find any signs of $A$. griseus. Most of the branches were 
probably too thin for the species. Larvae have been found in 3-12 cm diameter branches of pine in Gotska Sandön (Lundberg 1964).

\subsection{Identifying galleries and larvae}

The legless larva (Fig. 3) resembles that of $A$. aedilis, but does not grow bigger than $c a .18 \mathrm{~mm}$. For a description of the larva, see e.g. Teppner (1969) or Mamaev \& Danilevsky (1975). A key to the species is given by Švácha (2001). The larval galleries of $A$. griseus are also very similar to those of $A$. aedilis, but are considerably smaller in size. Larvae feed subcortically. Normally the larval gallery is almost entirely confined to the inner bark and only slightly touches the surface of the wood. Only if the bark is either very dry or thin are the galleries shallowly excavated into the wood surface. This also adds some whitish wood fibres to the otherwise rather unicolorous reddish or brownish frass. When pupation takes place inside sapwood or between bark and wood (Fig. 3), the frass filling the last $2 \mathrm{~cm}$ of the larval gallery is more or less whitish, consisting of fine wood fibres, which are also used to plug the entrance hole of the pupal chamber.

Normally the pupal chamber is excavated no deeper than 2-5 $\mathrm{mm}$ into the outer sapwood. The chamber is slightly curved, but lies flat and parallel to the surface (Fig. 4). In spruce trees, all the chambers I have seen were inside sapwood. In pine trees, however, the chamber is only located inside the sapwood when the bark is thin $(c a .0 .1-0.7 \mathrm{~cm})$. If the bark is $c a .0 .5-1 \mathrm{~cm}$ thick, the chamber is usually located between the bark and wood, shallowly excavated into the surface of the wood, and if the bark is thicker than $c a .0 .8 \mathrm{~cm}$, pupation takes place inside the bark. In such cases the pupal chamber is difficult to locate. The size of the entrance hole to the pupal chamber is $c a .4 \times 2.5 \mathrm{~mm}$, which is also the size of the oval exit hole in the bark (Fig. 4). Parasitised larvae are normally killed before they make any pupal chamber.

\subsection{Emergence of adults}

A large proportion of adults had already left the trees before I started the studies in the first week

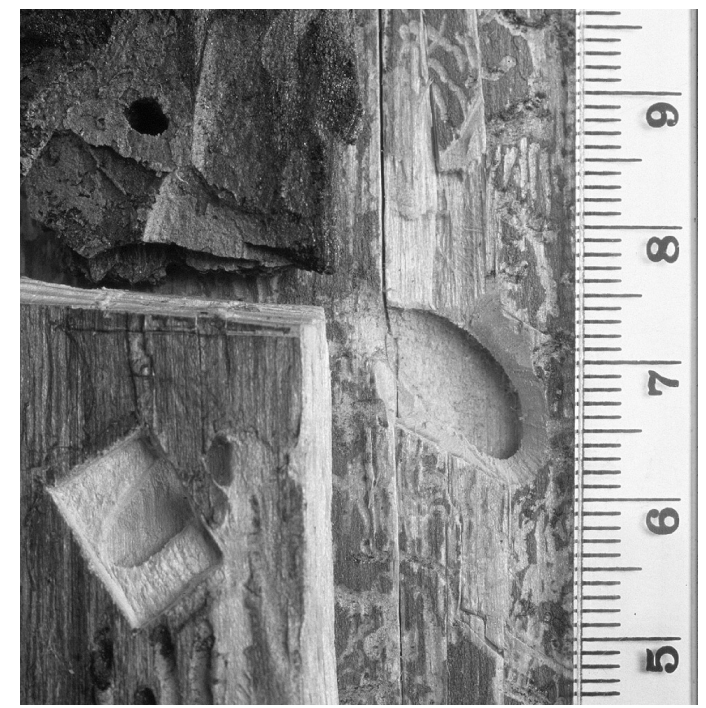

Fig. 4. Exit hole in the burned bark of pine (top left), and opened (right) and partly opened (bottom left) pupal chamber only a few $\mathrm{mm}$ below the surface wood of spruce. The oval entrance hole to the pupal chamber can be seen in the partly opened chamber.

of July, both in 1996 and 1997. Pupae that were removed from trees hatched on 15 and 25.VII.1996, and living adults still in their pupal chambers were observed on 9.VII.1996 and 3.VII.1997. Larvae which were reared in 1996 emerged as follows: 2 exx. on 9.VII., 1 ex. on 10.VII. and 4 exx. 11.18.VII.1997. However, these bolts were kept in a shady warehouse, where the temperature was probably lower than outdoors in summertime, and consequently, emergence may have been delayed. Some bolts containing larvae from the year 1997 were housed at room temperature from 13.I.1998, and four adults emerged 14.-19.II.1998. The larvae found in Russian Karelia in 4.V.1998 hatched after $c a$. two weeks at room temperature. In Finland, adults have been observed between 8 June and 17 September, but most of the findings have been made between late June and early July (Fig. 5).

\subsection{Generation time}

My observations suggest that the development normally takes two years in Finland. However, in several trees there were already a few empty pu- 


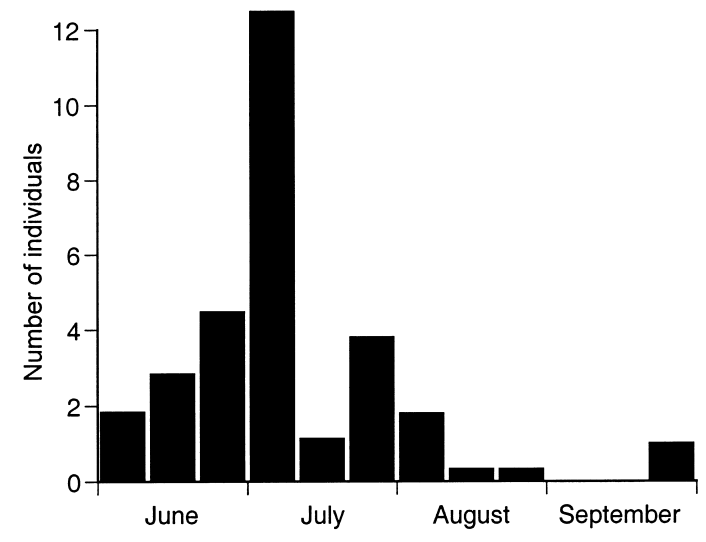

Fig. 5. Number of $A$. griseus individuals found in each 10-11 day period in Finland. Only adults found in the wild are included. Data concerning trapped individuals are divided into respective sampling periods.

pal chambers one year after the tree had died, although with many larvae remaining which would presumably have to overwinter again. This shows that some individuals can complete their development in one year. In unfavourable conditions development may even take three years, but desiccation of the bark and outer sapwood often leads to the death of larvae if the development is delayed. Complete development within one summer in Finland may not be possible, unlike in the case of the early flying A. aedilis. All specimens I have reared obviously overwintered in the larval stage. I have examined many pupal chambers late in the autumn and particularly in the spring, and found only larvae.

\subsection{Predation and parasitoids}

Mortality of A. griseus seems to be high during the larval stage due to parasitoids and predators. In many cases $80-90 \%$ of the larvae were parasitised. The larvae that have been attacked by parasitoids are killed prior to excavating pupal chambers. Larvae in their pupal chambers are often preyed upon by woodpeckers during the winter. On 4.IV.1999, I observed a three-toed woodpecker (Picoides tridactylus) peeling bark from burned pines in Puumala to eat, among other invertebrates, mature larvae of A. griseus directly from their pupal chambers.
I have reared several parasitoid species from the trees inhabited by A. griseus. However, only two species were definitely parasitising $A$. griseus. Xorides irrigator (Fabricius) (Hymenoptera: Ichneumonidae: Xoridinae; det. R. Jussila) was present in several trees in Juva and reared from larvae of $A$. griseus with certainty, and two specimens of the tachinid fly Billaea triangulifera (Zetterstedt) (Diptera: Tachinidae; det. A. Haarto) were reared from larvae of A. griseus (det. P. Švácha) sieved on 13 May 1998 from the bark of burned pine in $K b$ : Lieksa (7029:690). $X$. irrigator is known to parasitise Acanthocinus carinulatus Gebler, Rhagium inquisitor and Tetropium gabrieli Weise (Aubert 1969), and B. triangulifera is a parasitoid of several cerambycid genera, including Acanthocinus (Tschorsnig \& Herting 1994). In addition to these, Dolichomitus terebrans (Ratzeburg) (Hymenoptera: Ichneumonidae: Pimplinae; det. R. Jussila), a species especially attacking larvae of Pissodes spp. (Oehlke 1967), was once possibly reared from A. griseus in Juva. Meteorus corax Marshall (Hymenoptera: Braconidae: Euphorinae; det. M. Koponen), which was reared from the top of pine 3 in Juva, was apparently parasitising M. galloprovincialis, not A. griseus (Martikainen \& Koponen 2001).

\subsection{Records from Finland}

The records listed here and presented in Fig. 6 are based on specimens deposited in the collections of the Zoological Museum, University of Helsinki (ZMUH), Department of Applied Zoology, University of Helsinki (DAZH), Zoological Museum, University of Oulu (ZMUO), Zoological Museum, University of Turku (ZMUT) and private collections of several entomologists (abbreviations: first letter of first name and surname). A few records mentioned in the literature are included even if the actual specimens have not been seen.

\subsubsection{Before 1960}

Fennia, $10^{7}$, Ahlstr. (ZMUH). Ab: Kakskerta (labelled Kaxkerta), 2 ᄋ, Bonsd.; 1 \%, Pippingsk.; 1 
ơ, Ehrström (ZMUH). Kakkarainen (labelled Kakkarais), $10^{7}$, Pippingsk. (ZMUH). N: Helsinki, 17.IX.1863 1 \&, “Mus. Fenn.”; Helsinki, 1 O’, H. Sahlb. (ZMUH). St: Yläne, 10 o', C. Sahlb.; $10^{7} 1$ o, J. Sahlb. (ZMUH, ZMUT). Ta: Hämeenlinna, VI.1897, 1 \&, R. Krogerus (Coll. ?) (Saalas 1923). Lammi, Evo, 1 ㅇ, Furuhjelm, (Coll. E. Kangas in DAZH); Lammi, Evo, (with number 258 on green label), 1 ᄋ (Coll. Y. Kangas in ZMUT). Sa: Joutseno, 27.-30.VII.1945, 2 우 2 O', E. Thuneberg (ZMUH, Coll. E. Kangas in DAZH). Imatra, Asemäki, 2.VII.1948, 1 ᄋ, E. Thuneberg (ZMUH); Imatra, 2.VII.1948, 4 O’, E. Thuneberg (ZMUH, Coll. Y. Kangas in ZMUT, ZMUO); Imatra, 8.11.VI.1956, $10^{7}$, Hk. Lindberg, 1 ㅇ, M. Meinander (ZMUH). Oa: Vaasa (labelled Vasa) 1 \& 4 o', Lindström (ZMUH, Coll. Elfving in DAZH); Ostrob., Kolki, $10^{7}$ and another $10^{7}$ dated 22 Juni, both "Coll. Wasastj" (ZMUH). Tb: Saarijärvi, Pyhä-Häkki, 30.VI.1943, 1 O’, Krogerus, 2.VII.1943, 1 ơ, Stockmann (ZMUH)

\subsubsection{Years 1960-1985}

N: Espoo, Kolmperä, 7.VII.1972, 1 0', W. Hackm. (ZMUH), this specimen had been attracted to light (Hackman 1973); 668:36, 19.VI.1975, 1 ㅇ, W. Hackman (ZMUH). Helsinki, 668:38, 1 ex., reared, emerged III.1962, J. Perkiömäki leg. (Coll. JP); Helsinki, Munkkiniemi, 667:38, 3.5.VII.1974, 1 ex., car net, J. Muona leg. (Coll. JM) (Rutanen \& Muona 1982); Helsinki, Lehtisaari, 13.X.1984, larval galleries in pine logs, S. Lundberg (note: Rassi et al. (1985) report these two finds erroneously from the years 1976 and 1982, respectively). Ka: Karhula, Sunila, 3.VII.1985, 1 o', from flight, J. Siitonen leg. (Coll. JS). Kl: Uukuniemi, 6.VII.1982, 1 ex., sitting on a spruce bolt, Y. Ranta leg. (Coll. YR) (Ranta 1983). Kb: Lieksa, Suomunjärvi, 7.VII.1981, 1 옹 floating on water, J. Siitonen leg. (Coll. JS). Kn: Kuhmo, north of National park Ulvinsalo, 21-22.VI.1984, 3 o', by net from the evening flight near fresh timber piles, A. Nilsson \& R. Pettersson leg. (Coll. AN \& RP). Obb: Kemijärvi, Kostamo, 741:53, 1 ex., reared, emerged 1984, J. Muona leg. (Coll. JM) (note: Rassi et al. (1985) report this find erroneously from Rovaniemi municipality).

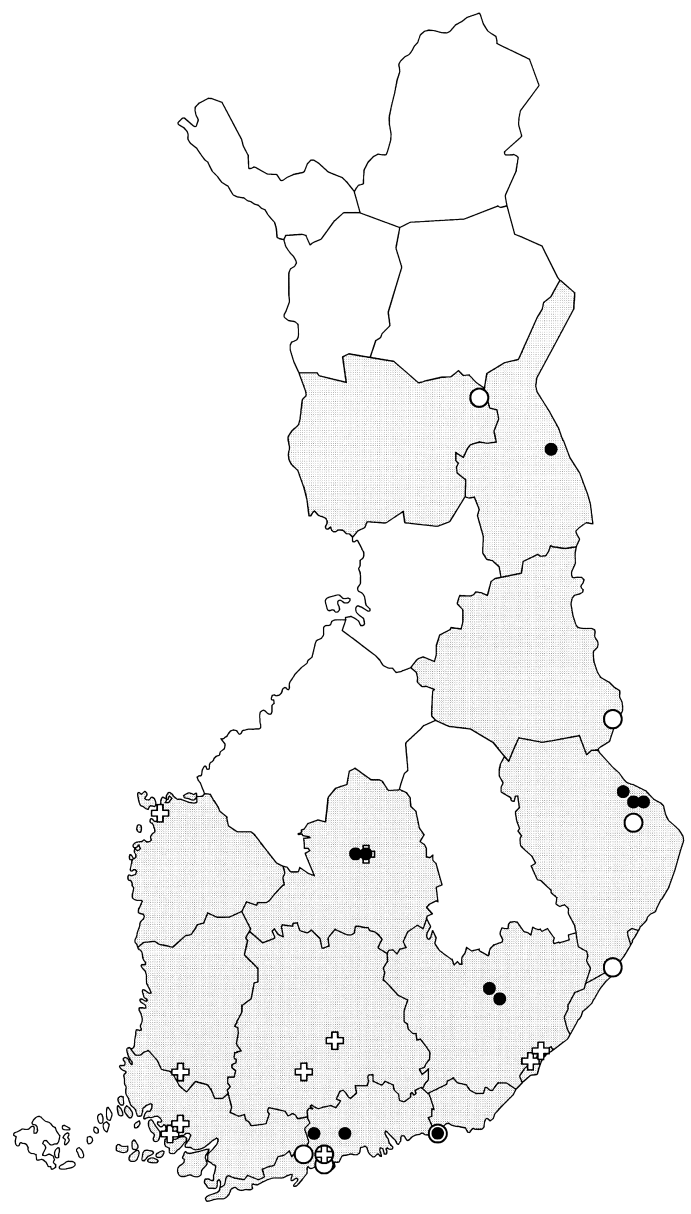

Fig 6. Distribution of $A$. griseus in Finland. Open crosses: records before 1960; open rings: records between 1960 and 1985; black dots: records after 1985.

\subsubsection{After 1985}

N: Sipoo, 6708:403, 1 larva, (emerged 7.XII.1997), from dead spruce attacked by Ips typographus (Linnaeus) at forest edge, I. Mannerkoski leg. (Coll. IM). Nurmijärvi, 6708:379, VII.2000, 1 ex, sitting on a spruce bolt, Heikki Kiuru leg. (Coll. HK). Ka: Kotka, Halla, 670:49, 4.VIII.1995, 1 o", to light between 3:00 and 3:30 a.m., J.-P. Kaitila leg. (Coll. JPK). Sa: Juva, Otamo, 6838:550-1, 1996-2001, larvae, pupae and adults in several trees, P. Martikainen leg. (Coll. PM); Juva, Koikkala, 6846:547, 13.III.2001, 6 larvae (P. Švácha det.), some reared to adults, P. Martikainen leg. (Coll. PM). Puumala, Linnomäki 6837:552, 
4.IV.1999, 5 larvae, reared to adults, P. Martikainen leg. (Coll. PM). Tb: Saarijärvi, PyhäHäkki, 24.VII.1989, 1 larva (emerged 10.I.1990), at the breast height of pine attacked by Tomicus minor (Hartig) in pine swamp, S. Lundberg leg. (Coll. IR); Saarijärvi, Sikomäki 69718:4199, 1.VII.-3.IX.1999, 2 exx., in window trap attached on burned spruce, P. Ahlroth, E. Hyvärinen \& J. Mattila leg. (Coll. Univ. Jyväskylä). Kb: Lieksa, 7029:690, 13.V.1998, 2 parasitized larvae (P. Švácha det.), P. Martikainen leg.; Lieksa, Kuikkavaara, 70329:6755, 28.VI.-18.VII.2001, 1 ᄋ in window trap on burned clearcut, J. Kouki, H. Lappalainen \& P. Martikainen leg. (Coll. Univ. Joensuu); Lieksa, Riihipetäikkö, 70256:6836, 16.VII.-9.VIII.2001, $1 \mathrm{O}^{7}$ in window trap on burned area, J. Kouki, H. Lappalainen \& P. Martikainen leg. (Coll. Univ. Joensuu), Ks: Kuusamo, 736:60, 1 ex., reared, emerged 25.VI.15.VII.1986, J. Muona leg. (Coll. JM).

\subsubsection{Unclear records}

I have not been able to verify two of the records listed in Rassi et al. (1985): Ta: Hämeenlinna, in the beginning of the 1970's, and Ta: Pälkäne 1984.

\section{Discussion}

Observations on the natural history of $A$. griseus have been very scattered so far in the Nordic countries and most of the records, particularly in Finland, have been based on accidentally encountered adult beetles. Consequently, the few actual findings on the biology have considerably influenced assumptions regarding habitat requirements of A. griseus. For instance, the observations made in Gotska Sandön by Lundberg (1964) have apparently contributed to the view that $A$. griseus is a species living under thin bark in the canopies of windthrown pine and spruce trees in old, primeval forests (see Rassi et al. 1985, Ehnström \& Waldén 1986). Descriptions on the biology of A. griseus in many Central European handbooks are superficial and almost identical, stating usually that host plants are Pinus, Picea and Abies, and that larvae live in unhealthy or recently dead stems and fallen branches with a minimum diameter of $3 \mathrm{~cm}$ - a diameter given originally by Lundberg (1964) (e.g. Demelt 1966, Horion 1974, Bense 1995).

The habitat requirements of A. griseus are indeed rather broad. It can successfully develop in nearly any part of the trunk regardless of the thickness of the bark, both in spruce and pine. It does not require (although it may prefer) particularly old or burned trees, nor stands in natural condition. The forests in the study areas in Juva are in normal silvicultural use and dead pine and spruce trees killed by Heterobasidion spp. and Endocronartium pini are equally common in many regions in southern Finland. All the trees examined were located in normal thinned stands, some at sunny forest edges. Also the dead trees were "normal", and similar dead trees can be found throughout southern Finland.

Why, then, is A. griseus seen so rarely? There are probably many reasons. Firstly, until now it has not been clear how this species should be looked for. Focused, intensive examination of suitable trees would without doubt reveal many new occurrences. The same was true e.g. in the case of Leiopus punctulatus (Paykull) in Sweden recently (Lundberg \& Martin 1991, Lundberg 1996). Many standing spruce and pine trees are often rather species poor 1-2 years after their death, and consequently seldom studied, especially at heights above $2 \mathrm{~m}$. However, perhaps over $90 \%$ of the larvae are located higher in standing trees than can be reached from the ground. In the basal part of the trunk, signs of A. griseus are often very difficult to distinguish from other cerambycids and pupal chambers are hidden in the bark. Examination of the whole trunk requires felling of the tree which is not often possible. It is very likely that $A$. griseus prefers standing trees to fallen trees. I have not seen any signs of this species in recent windfalls despite eager searching. Furthermore, a small experiment in Juva where one living spruce was felled and another was girdled to die standing resulted in only the standing tree being successfully colonised by $A$. griseus.

A second reason for the poor observability of A. griseus is that adults live a cryptic life. They may spend much of their time high up in the trees: A. griseus has been recorded twice from the top part of a dead tree just after the tree had been felled 
(Saalas 1923 and pers. obs.). It is also probable that $A$. griseus does not often visit timber piles, because if it did, there would be significantly more observations. Some Finnish observations also support the view that $A$. griseus is active in the evening and during the night and is attracted by light (e.g. Horion 1974, Bense 1995): at least twice it has been caught through the use of light in Finland (Hackman 1973, J.-P. Kaitila pers. comm.).

It seems that $A$. griseus can literally live in an entomologist's backyard with only a small risk of ever being detected by normal sampling methods. In fact, I have collected insects intensively for 20 years in the areas in Juva where I have now found plenty of trees inhabited by A. griseus. If I had not originally met this species accidentally in 1996, I still would not have any idea that it occurs commonly in dead standing spruce and pine trees in the places I frequently visit in my home district.

Successfully surveying for A. griseus apparently requires detailed, laborious examination of suitable trees. Spruce or pine trees that have died in the previous year have to be felled and peeled carefully throughout, which takes several hours per tree. The best time for doing this is obviously between late autumn and early June, when larvae are already in their pupal chambers. Rearing is easiest when the whole pupal chamber is removed from the trunk in a $1-\mathrm{cm}$ thick and $10-\mathrm{cm}$ wide chip using an axe or a saw.

To conclude, A. griseus is clearly an overlooked species that probably occurs throughout the southern half of Finland and does not need to be included in the list of threatened species, unless future studies show otherwise.

Acknowledgements. I am very grateful to Seppo Valmula for help and for allowing me to conduct studies in his forest in Juva. Petri Ahlroth, Bengt Ehnström, Esko Hyvärinen, Oskari Härmä, Jari-Pekka Kaitila, Heikki Kiuru, Martti Koponen (DAZH), Frank Köhler, Erkki Laurinharju, Stig Lundberg, Ilpo Mannerkoski, Jaakko Mattila, Jyrki Muona, Anders Nilsson, Jonny Perkiömäki, Roger Pettersson, Pertti Rassi, Pertti Renvall, Veikko Rinne (ZMUT), Ilpo Rutanen, and Juha Siitonen are thanked for information on the species and Antti Haarto, Reijo Jussila, Martti Koponen, Petr Švácha and Veli Vikberg for identifying parasitoids and larvae. I am also grateful to Jari Ilmonen (Finnish Environment Institute) who produced the distribution map, and to Åke Lindelöw, Juha Siitonen and Niklas Wahlberg for valuable comments on the manuscript.
Simon Grove kindly improved the language. This study was partly funded by the Academy of Finland (Finnish Centre of Excellence Programme 2000-2005, project no. 64308).

\section{References}

Anon. 1999: Nasjonal rødliste for truete arter i Norge 1998. — Direktoratet for naturforvaltning. DN-rapport 1999-3.

Aubert, J.-F. 1969: Les Ichneumonides Ouest-Paléarctiques et leurs hôtes, 1 Pimplinae, Xoridinae, Acaenitinae. Quatre Feuilles Editeur, Paris. 299 pp.

Baranowski, R. 1980: Några bidrag till kännedomen on coleopterfaunan vid nedre Dalälven. 2. — Ent. Tidskr. 101: 29-42.

Bense, U. 1995: Longhorn beetles. Illustrated key to the Cerambycidae and Vesperidae of Europe. - Margraf Verlag, Germany. 512 pp.

Bílý, S. \& Mehl, O. 1989: Longhorn beetles (Coleoptera, Cerambycidae) of Fennoscandia and Denmark. Fauna Ent. Scand. 22.

Demelt, C. 1966: Bockkäfer oder Cerambycidae. I. Biologie mitteleuropäischer Bockkäfer (Col. Cerambycidae) unter besonderer Berücksichtigung der Larven. - In: Dahl, F. (ed.), Die Tierwelt Deutschlands und der angrenzenden Meeresteile, 52. teil. 115 pp.

Ehnström, B. \& Waldén, H. W. 1986: Faunavård i skogsbruket - Den lägre faunan. - Skogsstyrelsen, Jönkoping. 351 pp.

Ehnström, B., Gärdenfors, U. \& Lindelöw, A. 1993: Rödlistade evertebrater i Sverige 1993. — Databanken för hotade arter. Uppsala.

Geiser, R. 1998: Rote Liste der Käfer (Coleoptera). — In: Binot, M., Bless, P., Boye, P., Gruttke, H. \& Pretscher, P. (eds.), Rote Liste gefährdeter Tiere Deutschlands: 168-230. Schrr. Landschaftspflege Natursch. 55.

Hackman, W. 1973: Mötesreferat - Kokousselostuksia. — Notul. Entomol. 53: 171.

Horion, A. D. 1974: Faunistik der mitteleuropäischen Käfer. Band XII: Cerambycidae. — Überlingen-Bodensee.

Klausnitzer, B. \& Sander, F. 1978: Die Bockkäfer Mitteleuropas. — Ziemsen Verlag, Wittenberg. 222 pp.

Lundberg, S. 1964: Bidrag till kännedom om skalbaggsfaunan på Gotska Sandön. — Ent. Tidskr. 85: 45-48.

Lundberg, S. 1996: Bidrag till kännedomen on svenska skalbaggar 24. - Ent. Tidskr. 117: 124-125.

Lundberg, S. \& Martin, O. 1991: Leiopus punctulatus (Coleoptera, Cerambycidae) återfunnen i Sverige med uppgifter om biologin. — Ent. Tidskr. 112: 129-132.

Lundberg, S. \& Pettersson, R. 1997: Något om skalbaggsfaunan i Ryskt virke vid en såg i Västerbotten. — Ent. Tidskr. 118: 49-51.

Mamaev, B. M. \& Danilevsky, M. L. 1975: [Larvae of longhorn beetles]. - Nauka, Moscow. 282 pp. [In Russian].

Martikainen, P. 2000: Flight period and ecology of Trypodendron proximum (Niijima) (Col., Scolytidae) in Finland. - J. Appl. Ent. 124: 57-62. 
Martikainen, P. \& Koponen, M. 2001: Meteorus corax Marshall, 1898 (Hymenoptera, Braconidae), a new species to Finland and Russian Karelia, with an overview on northern species of Meteorus parasitizing beetles. — Entomol. Fennica 12: 169-172.

Martikainen, P. \& Niemelä, P. 2000: Muistiinpanoja hyönteiskeräysretkeltä Sortavalan seudun metsiin keväällä 1998. - Sahlbergia 5: 29-32.

Oehlke, J. 1967: Westpaläarktische Ichneumonidae 1: Ephialtinae - In: Ferrière, C. \& van der Vecht, J. (eds.), Hymenopterorum Catalogus (nova editio) Pars 2: 149.

Palm, T. 1984: Svenska fynd av larven till långhorningen Acanthocinus griseus F. - Ent. Tidskr. 105: 155.

Ranta, Y. 1983: Kolme mielenkiintoista sarvijäärä-löytöä (Cerambycidae). — Notul. Entomol. 63: 214.

Rassi, P., Alanen, A., Kemppainen, E., Wickholm, M. \& Väisänen, R. 1985: Uhanalaisten eläinten ja kasvien suojelutoimikunnan mietintö. - Komiteanmietintö 1985: 43.466 pp.

Rassi, P., Kaipiainen,H., Mannerkoski, I. \& Ståhls, G. 1992: Uhanalaisten eläinten ja kasvien seurantatoimikunnan mietintö. — Komiteanmietintö 1991: 30. 328 pp.
Rassi, P., Alanen, A., Kanerva, T. \& Mannerkoski, I. (eds.) 2001: Suomen lajien uhanalaisuus 2000. — Ympäristöministeriö \& Suomen ympäristökeskus, Helsinki.

Rutanen, I. \& Muona, J. 1982: Coleoptera collected with a car net in Finland. - Notul. Entomol. 62: 69-72.

Saalas, U. 1923: Die Fichtenkäfer Finnlands II. - Ann. Acad. Scient. Fenn. Ser. A. 22: 1-746.

Silfverberg, H. 1992: Enumeratio Coleopterorum Fennoscandiae, Daniae et Baltiae. - Helsingin Hyönteisvaihtoyhdistys, Helsinki.

Švácha, P. 2001: Cerambycidae, Lamiinae. — In: Klausnitzer, B. (ed.), Die Larven der Käfer Mitteleuropas: 248-298. Spektrum, Akad. Verl. Heidelberg; Berlin. 309 pp.

Teppner, H. 1969: Bestimmungstabelle mitteleuropäischer Lamiinae-larven (Coleoptera, Cerambycidae) mit Bemerkungen zu deren Biologie. - Verh. Zool.-Bot. Ges. Wien 108-109 (1968-69):19-58.

Tschorsnig, H.-P. \& Herting, B. 1994: Die Raupenfliegen (Diptera, Tachinidae) Mitteleuropas: Bestimmungstabellen und Angaben zur Verbreitung und Ökologie der einzelnen Arten. - Stuttgarter Beiträge zur Naturkunde, Serie A (Biologie). 